\title{
Pendidikan Karakter dalam Perspektif Profetik pada Puisi-Puisi Abdul Wachid B.S.
}

\author{
Mahroso Doloh \\ Universitas Negeri Yogyakarta (UNY) \\ Corresponding e-mail : mahroso_doloh@yahoo.com
}

\begin{abstract}
This study aims to examine and describe prophetic values in the poems of Abdul Wachid B.S. as something that can drive the success of character education in a prophetic perspective. The approach used in this research is Riffaterre semiotic approach with qualitative descriptive analysis method. The results of the study were found as follows. There are values or matters related to the three prophetic pillars: first, the humanization pillars are as follows: (1) calling for brotherhood, (2) solidarity on the basis of humanity, and (3) noble values maintained in the face of rapid technological developments. Second, the pillars of liberation contain the following: (1) sympathy by voicing the voice of liberation for the workers, (2) the effort to improve human dignity, and (3) there is an element of unwillingness against injustice prevailing on this earth. Third, the transcendental pillars that vocalize some matters relating to transcendence are: (1) establishing a servant's trust in God, (2) awakening the weakness of man, so that he must always be dependent on God, and (3) should always remind God in any circumstance. From some of the things that appear on the prophetic pillars it is an education that educates the nation's children (the readers) to achieve a prophetic character or it can be said an education that encourages the success of character education (especially character education in the prophetic perspective).
\end{abstract}

Keyword: character education, prophetic, poetry of Abdul Wachid B.S.

Abstrak. Penelitian ini bertujuan untuk mengkaji dan mendeskripsikan nilai-nilai profetik pada puisi-puisi Abdul Wachid B.S. sebagai sesuatu yang dapat mendorong keberhasilan pendidikan karakter dalam perspektif profetik. Pendekatan yang digunakan pada penelitian ini adalah pendekatan semiotik Riffaterre sekaligus dengan metode analisis deskriptif kualitatif. Hasil penelitian yang didapati sebagaimana berikut ini. Terdapat nilai-nilai atau hal-hal yang terkait dengan tiga pilar profetik, yaitu pertama, pada pilar humanisasi terdapat beberapa hal berikut: (1) seruan menjalin tali persaudaraan, (2) solidaritas atas dasar kemanusiaan, dan (3) nilai-nilai luhur yang harus dijaga dalam menghadapi perkembangan teknologi yang begitu pesat. Kedua, pilar leberasi yang memuat hal berikut: (1) rasa simpati dengan menyuarakan suara pembebasan bagi para buruh, (2) upaya meningkatkan martabat manusia, dan (3) ada unsur tidak rela terhadap ketidakadilan yang berlaku di muka bumi ini. Ketiga, pilar transendensi yang menyuarakan beberapa hal terkait dengan transendensi, yaitu (1) menegakkan kepercayaan seorang hamba kepada Allah, (2) menyadarkan tentang lemahnya manusia sehingga harus senantiasa bergantung kepada Allah, dan (3) harus senantiasa mengingatkan Allah dalam keadaan apapun. Beberapa hal yang muncul pada pilar-pilar profetik itu merupakan sebuah edukasi yang mendidik anak bangsa (para pembaca) untuk mencapai sebuah karakter profetik atau dapat 
dikatakan sebuah edukasi yang mendorong keberhasilan pendidikan karakter (terutama pendidikan karakter dalam perspektif profetik).

Keyword: pendidikan karakter, profetik, puisi Abdul Wachid B.S.

\section{PENDAHULUAN}

Dewasa ini masyarakat Indonesia sering terdengar berita-berita yang tidak menyenangkan. Berbagai masalah yang berlaku disebabkan buruknya karakter seorang manusia yang menjadi bagian dari masyarakat bangsa ini. Berbagai masalah yang muncul, tidak hanya berlaku pada suatu fase kehidupan tertentu saja, tetapi berlaku pada setiap fase kehidupan manusia. Namun, pada setiap masingmasing fase mempunyai masalah yang berbeda tergantung dengan dunia atau status yang sedang berlaku pada diri seseorang. Masalah yang sering terdengar pada hari ini, di antaranya pelajar atau siswa tidak lagi mengenal adab atau sopan santun terhadap gurunya bahkan berani melawan sehingga terkadang para guru harus menjadi korban. Para remaja bergaulan bebas antara laki-laki perempuan tanpa mempeduli ajaran atau batas-batas agama, sehingga muncul masalah hamil sebelum menikah yang terkadang sampai pada membuang bayi yang dilahirkan karena tidak tahu siapa yang menjadi bapak seorang bayi yang dilahirkan itu.

Setelah dari masalah siswa atau remaja, terdapat pula masalah yang berlaku pada orang dewasa. Jika dalam konteks pejabat atau pegawai pemerintah, masalahnya adalah korupsi yang tidak tahu kapan akan berakhir. Jika dalam konteks organisasi atau kelompok, masalahnya adalah saling fitnah memfitnah, mengadu domba sehingga terkadang harus berperang antara dua kelompok tertentu yang sama-sama berteriak dengan mentakbirkan Allah Akbar. Dalam konteks agama, di antara masalahnya adalah muncul para kiai amplop yang berani menghalalkan yang haram dan mengharamkan yang halal demi mendapatkan bayaran berbentuk uang (sebagaimana sering terdengar olok olokan di kalangan masyarakat). Dari berbagai masalah tersebut, dapat dikatakan bahwa faktor utama yang menimbulkan masalah itu adalah berawal dari manusia yang berkarakter buruk. Oleh karena itu, pendidikan karakter perlu dibahas dan ditingkatkan lagi keseriusannya sehingga masalah-masalah tersebut dapat diminimalisir atau dapat dituntaskan secara total.

Sejalan dengan apa yang dikatakan oleh Roqib (2013: 241) bahwa dalam konteks pendidikan di negeri ini telah gagal membentuk watak atau pribadi yang mempunnyai karakter sehat dan positif. Fakultas hukum di perguruan tinggi belum mampu membentuk kader pemimpin bangsa yang tangguh dan dapat memperjuangkan hukum agar dapat berjalan dengan baik dan benar di masyarakat. Sementara itu, fakultas ilmu polotik belum mampu membentuk politisi yang santun dan berpihak pada kesejahteraan rakyat. Lembaga pendidikan, juga kecolongan dengan banyaknya para peserta didik yang miskin moral dan melanggar ajaran agama.

Berdasarkan berbagai masalah yang muncul itu, menjadi suatu kegelisahan bagi penulis yang sekaligus juga ingin memperingatkan kembali terkait dengan dunia sastra Indonesia yang tentunya tidak akan muncul dari kekosongan budaya luhur, yang artinya dalam sebuah karya sastra pasti mengandung berbagai nilai luhur yang dapat mendorong masyarakat untuk menjadi manusia yang berkarakter dalam rangka mencapai 
dangan apa yang disebut dengan "khalifah Allah" di muka bumi ini. Pradopo (2012: 3) menegaskan bahwa puisi (karya sastra) itu karya estetis yang bermakna, yang mempunyai arti, bukan hanya suatu yang kosong tanpa makna. Dengan demikian, ketika berbagai masalah muncul di masyarakat maka sastra tidak boleh diam lagi. Artinya, sastra harus bergerak dengan menawarkan solusi atau sesuatu yang dapat mendorong dalam proses pencapaian keberhasilan dalam penyelesaian masalah-masalah atau mendorong dunia pendidikan yang disebut dengan pendidikan karakter.

Terkait dengan dunia pendidikan, dalam perspektif profetik atau kenabian adalah sebuah usaha yang mengkaji terkait dengan konsep pendidikan sebagai suatu program besar suatu bangsa yang memiliki kekuatan produktif masa depan yang gemilang sebagaimana yang dilakukan oleh seseorang yang disebut sebagai nabi; orang yang berbicara awal atau pelopor yang memproklamasikan diri dan berbicara masa depan (Eliadem 1987: 16). Sementara dunia sastra, terutama yang disebut dengan sastra profetik sebagaimana yang dikemukakan oleh Kuntowijoyo (2006) bahwa karya sastra yang baik adalah karya sastra yang mampu menjalankan tiga peran atau tiga pilar demi kesempurnaan misi profetik. Adanya tiga pilar tersebut, karya sastra akan mempunya peran dalam menyadarkan para membaca tentang pentingnya melakukan amar ma'ruf (humanisasi), nahi munkar (liberasi), dan tu'minu billah (transendensi). Dengan demikian, karya sastra dapat menjadi sebuah media dakwah atau sebuah media yang dapat mendorong dunia pendidikan, terutama pendidikan karakter dalam perspektif profetik.

Sastra profetik di Indonesia, memang bukanlah hal yang baru. Akan tetepi, sastra profetik memiliki misi yang relevan dengan apa yang sedang berlaku pada masyarakat saat ini. Oleh karena itu, sangat disayangkan jika produk (sastra profetik) itu tidak digunakan dalam menunjang keberhasilan terhadap pendidikan bangsa ini. Terikait dengan itu, pada penelitian ini akan mencoba menganalisis dan mendeskripsikan nilainilai profetik pada puisi-puisi Abdul Wachid B.S. yang sekaligus dapat mendidik para pembaca untuk menjadi manusia yang berkarakter profetik. Para penyair Indonesia, tidaklah sedikit yang menulis puisi-puisi profetik. Salah satu di antaranya adalah Abdul Wachid B.S. sebagaimana ia telah tercatat pada sejarah sastra Indonesia bahwa Abdul Wachid B.S. merupakan seorang penyair sufi yang tentunya tidak terlepas dengan membawa visi profetik di dalam puisi-puisinya. Kurniawan (2009: 4) mengemukakan bahwa dalam sejarah sastra Indonesia, Abdul Wachid B.S. merupakan salah satu sastrawan yang berbasis Islam. Artinya, puisi-puisi yang ditulis oleh Abdul Abdul Wachid B.S. banyak menawarkan wacanawacana terkait dengan Islam.

Tulisan ini merupakan sebagian hasil dari sebuah penelitian yang penulis lakukan dalam rangka mendapatkan gelar Magister Pendidikan di Universitas Negeri Yogyakarta. Puisi-puisi yang dianalisis adalah puisi yang terdapat pada kumpulan puisi karya Abdul Wachid B.S. yang meliputi: (1) Rumah Cahaya (2003), (2) Tumjammu Kekasih (2003), dan (3) Nun (2017).

\section{METODE PENELITIAN}

Puisi-puisi Abdul Wachid B.S. dipandang sebagai salah satu karya sastra (puisi) profetik yang dapat mendorong terkait dengan hal dunia pendidikan karakter. Hal tersebut, dipahami dengan 
menggunakan konsep penelitian kualitatif dengan metode analisis deskriptif. Sementara teori atau pisau analisisnya adalah teori semiotik Riffaterre. Metode dan teori tersebut, digunakan dalam proses analisis dan mendeskripsikan nilainilai profetik yang terdapat pada puisipuisi Abdul Wachid B.S. sebagai salah satu hal yang dapat mendorong keberhasilan pendidikan karakter (terutama dalam perspektif profetik). Sumber data penelitian adalah puisi-puisi yang terdapat pada tiga buah kumpulan puisi karya Abdul Wachid B.S., yaitu Rumah Cahaya (2003), Tunjammu Kekasih (2003), dan Nun (2017). Data penelitian adalah berupa kata, frase, atau kalimat-kalimat yang ada pada bait-bait puisi karya Abdul Wachid B.S.

Semiotik adalah pendekatan yang memandang karya sastra sebagai sistem tanda (Wiyatmi, 2008: 92). Senada dengan apa yang disampaikan oleh Teew, (1984: 142) bahwa ilmu sastra yang sejati harus bersifat semiotik, yaitu harus menganggap sastra sebagai sistem tanda. Terkait dengan itu, peneliti akan menganalisis puisi-puisi Abdul Wachid B.S. sesuai dengan cara kerja teori semiotik Riffaterre. Semiotik Riffaterre sebagaimana yang disampaikan oleh Pradopo (2012: 281) bahwa Riffaterre mengemukakan empat hal yang menjadi pokok untuk memproduksi makna/konkretisasi puisi, yaitu: (1) ketidaklangsungan ekspresi, (2) pembacaan heuristik dan retroaktif atau hermeneutik, (3) matrix atau kata kunci (key word), dan hypogram (hipogram berkenaan dengan prinsip intertekstual).

Sementara ketidaklangsungan ekspresi dalam puisi (Riffaterre, 1978: 2) menyatakan bahwa ada tiga hal, yaitu 1) pergantian arti (displacing of meaning), 2) penyimpangan arti (distorting ofmeaning), dan 3) penciptaan arti (creating of meaning). Adanya pergantian arti disebabkan oleh metafora dan metonimi, yaitu bahasa kiasan pada umumnya. Adapun penyimpangan arti, disebabkan oleh ambigiutas dan nonsense. Sementara penciptaan arti disebabkan oleh pengorganisasian ruang teks, di antaranya enjambement, persajakan, tipografi dan homologue. Adanya ketiga hal tersebut, membuat puisi bukan sekedar mimesis atau tiruan realitas. Akan tetepi, puisi dapat dijadikan sebagai cerminan bagi masyarakat dan bahkan lebih dari itu. Dengan demikian, pada penelitian ini peneliti menganalisis puisi-puisi karya Abdul Wachid B.S. yang telah dipilih dengan mempertimbangkan adanya unsur-unsur atau nilai-nilai profetik yang dapat menjadi sesuatu dalam mendorong keberhasilan pendidikan karakter, terutama pendidikan karakter dalam perspektif profetik.

\section{HASIL DAN PEMBAHASAN}

Hasil yang terdapat pada penelitian ini adalah terkait dengan puisi Abdul Wachid B.S. sebagai suatu edukasi pendidikan karakter dalam perspektif profetik. Adapun karakter profetik yang terdapat pada puisi-puisi Abdul Wachid B.S. meliputi beberapahal yang muncul pada tiga pilar profetik, yaitu (1) pada pilar humanisasi, (2) pada pilar libersa, dan (3) pada pilar transendensi. Terkait dengan pembahasan terhadap beberapa hal itu, dapat disimak pada pembahasan berikuti ini.

\section{A. Nilai-nilai dan Pendidikan Karakter dalam Perspektif Profetik}

Terkait dengan nilai, ada berbagai paparan yang berbeda-beda dari para ahli. Namun, secara garis besarnya adalah sama. Menurut Allport (1964: 86), nilai adalah keyakinan yang membuat seseorang bertindak atas dasar pilihannya. Sementara Rocheah M. (1973: 79), menjelaskan bahwa nilai dapat dibedakan antara lain nilai instrumental dan nilai 
akhir sebagai nilai terminal. Nilai instrumental berwujud presentasi diri orang lain, evaluasi, justifikasi dan perbandingan diri sendiri dengan orang lain yang kemudian berujung pada nilai terminal, yang secara konsisten telah dimiliki oleh individu yaitu menjiwai tingkah laku dan kebiasaan sehingga menjadi karakter. Adapun menurut Kupperman (1983: 98), nilai adalah patokan normatif yang mengpengaruhi manusia dalam menentukan pilihannya di antara cara-cara tindakan alternatif. Senada dengan yang disampaikan oleh Hariyono (2000: 39) bahwa nilai adalah sesuatu yang dijunjung tinggi kebenarannya serta memiliki makna dan dijaga kebenarannya.

Selain dari itu, Skolimowsky (2004: 79) menjelaskan bahwa nilai memiliki dimensi yang sangat luas. Nilai mencakup seluruh aspek kehidupan manusia. Nilai juga mengatur hubungan antara Tuhan selaku Sang Pencipta dan manusia selaku ciptaan-Nya. Dalam hal ini, nilai berhubungan dengan pribadi antara seorang manusia dan Tuhan. Artinya, nilai menjelaskan kewajiban manusia terhadap Tuhan dan juga kewajiban manusia terhadap sesama (manusia). Sementara itu, manusia hidup di alam semesta maka harus pula terjalin hubungan baik antara manusia dangan alam, yaitu menjelaskan tentang kewajiban manusia dalam mengatur alam semesta. Berdasarkan pendapat para ahli terkait dengan nilai, dapat disimpulkan bahwa nilai adalah segala sesuatu yang diyakini baik dan benar oleh konvensional sebuah masyarakat. Sementara itu, pada konteks ini akan diarahkan pada nilai-nilai pendidikan karakterk dalam perspektif profetik. Oleh karena itu, nilai pada konteks ini dapat diartikan sebagai sesuatu yang ada keterkaitan dengan nilainilai kenabian yang tentunya bermanfaat dan dapat mendorong terhadap dunia pendidikan karakter untuk mencapai tujuan yang dinginkan.

Sementara definisi pendidikan karakter memiliki berbagai definisi yang berbedabeda; tergantung sudut pandang, paradigma, basis, keilmuan, dan pendekatan yang dipakai (Wibowo, 2013: 10). Adapun pendidikan karakter menurut Lickona adalah pendidikan yang memiliki tiga unsur pokok, yaitu mengetahui kebaikan (knowing the good), mencipta kebaikan (desiring the good), dan melakukan kebaikan (doing the good) (Wibowo, 2013: 15). Sementara itu, Roqib (2013: 244) mengemukakan bahwa pendidikan karakter dalam perspektif profetik adalah sebuah pendidikan yang didasari oleh nilai-nilai kenabian. Nilainilai tersebut telah pun terbukti bahwa mampu mengubah peradaban manusia menjadi lebih baik. Nilai-nilai profetik atau kenabian yang utama adalah sifatsifat wajib bagi rasul, yaitu shiddiq (jujur), amanah, tabligh (komunikatif), dan fathanah (cerdas). Adapun kontekstualisasi dari keempat sifat kenabian itu ialah terbentuk figur sebagai berikut. Pertama, selalu berpedoman pada nurani dan kebenaran, tidak mengikuti hawa nafsu dan pengaruh lingkungan yang negatif, bahkan ia yang telah terinternalisasi nilai profetik akan menebarkan kebenaran dan nilai kemanusiaan ke berbagai kalangan.

Kedua, figur tersebut juga menjaga profesionalisme dan komitmen. Apa yang ia dikatakan akan dilaksanakan dengan konsekuen. Ia menjadi seorang figur yang mampu menjaga amanah, tugas pokok, dan fungsinya sehingga tidak tenggelam dalam rayuan nafsu untuk menguasai jabatan atau kekayaan. Ia akan terus berbuat sesuai dengan mandat yang ia terima. Ketiga, figur ini menguasai keterampilan berkomunikasi dengan 
berbagai kalangan dan strata. Ia tidak membedakan suku, agama, partai politik, dan golongan. Kebenaran ia tegakkan dan komunikasikan ke berbagai kalangan dengan niatan untuk memberi kemanfaatan dan kedamaian hidup. Ucapan dan perilakunya sekaligus menjadi duta yang mampu menerjemahkan apa yang ada di hatinya secara jujur. Keempat, ia menjadi figur yang mampu menyelesaikan masalah karena memiliki multikecerdasan. Ia menjadi sosok kunci (key person) yang mampu menyelesaikan berbagai kasus dan problem yang muncul. Ia juga sosok yang mampu memanfaatkan fasilitas dan lingkungan baik fisik maupun sosial untuk mendukung pencapaian tujuan mulianya. Empat figur kenabian tersebut, dapat mengantarkan sebuah proses pendidikan karakter untuk mencapai tujuan yang diinginkan sebagaimana dalam perspektif pendidikan profetik. Adapun tujuan pendidikan profetik sebagaimana yang dikemukakan oleh Roqib (2011: 125), yaitu tidak terlepas dari prinsip-prinsip pendidikan yang bersumber dari nilainilai al-Qur'an dan as-Sunnah.

\section{B. Puisi Profetik Abdul Wachid B.S. sebagai Nilai Keberhasilan Pendidikan Karakter dalam Perspektif Profetik}

Sebelum membasah terkait dengan pilar-pilar profetik, ada baiknya dipahami terlebih dahulu tentang sastra (puisi) profetik. Sastra profetik dapat diartikan sebagai sastra agama yang di dalamnya tidak hanya memiliki dimensi atau nilainilai transendetal saja, tetapi juga memuat dimensi atau nilai-nilai sosial terkait dengan sifat kemanusiaan. Terkait dengan sosial dan profetik, Kuntowijoyo (2007: 99) menyatakan bahwa dalam ilmu sosial profetik memiliki tiga pilar yang harus disampaikan kepada mesyarakat, yaitu amar ma'ruf (humanisasi), nahi'munkar (liberasi), dan tu'minubillah (transendensi). Sementara itu, Hadi WM (1989: 23) menyatakan bahwa sastra profetik merupakan sastra yang berjiwa transendental dan sufistik karena berangkat dari nilai-nilai ketauhidan, tetapi yang setelah itu juga memiliki semangat untuk terlibat dalam mengubah sejarah kemanusiaan yang karena itu memiliki semangat kenabian.

Kuntowijoyo (2006: 1-2) menegaskan bahwa sastra profetik mempunyai kaidahkaidah yang memberi dasar kegiatannya, sebab ia tidak saja menyerap, mengekspresikan, tetapi juga memberi arah realitas. Sastra profetik adalah juga sastra dialektik, artinya sastra yang berhadap-hadapan dengan realitas, melakukan penilaian, dan kritik sosialbudaya secara beradap. Oleh karena itu, sastra profetik adalah sastra yang terlibat dalam sejarah kemanusiaan. Ia tidak mungkin menjadi sastra yang terpencil dari realitas. Akan tetepi, sastra hanya dapat berfungsi sepenuhnya bila ia sanggunp memandang realitas dari suatu jarak, karena itulah lahir ungkapan "sastra lebih luas dari realitas", "sastra membawa manusia keluar dari belenggu realitas", atau "sastra membangun realitasnya sendiri". Ia adalah renungan tentang realitas. Realitas sastra adalah realitias simbolis bukan realitas aktual dan realitas historis. Melalui simbol itulah sastra memberi arah dan melakukan kritik atas realitas.

Hilmy (2008: 108) memaparkan bahwa dalam kerangka sastra profetik yang menjadi penekanannya adalah bagaimana upaya yang harus dilakukan secara terusmenerus demi menjabarkan substansi nilai-nilai agama ke dalam kehidupan nyata. Aktivitas tersebut dapat dianalogikan dengan istilah "menghadirkan Tuhan" di ruang publik. Dalam arti, adanya sebuah usaha dalam melaksanakan makna-makna yang disebut 
"amar ma'ruf nahi mungkar" sehingga dapat menuju pada rahmatan lil 'alamin. Kuntowijowo (2006: 4) menyampaikan bahwa dalam konteks perjalanan sastra profetik, pengarang juga harus berkarya dengan mempunyai niat sebagai ibadah demi mencapai apa yang disebut dengan kaffah (Utuh). Tegas Kuntowijoyo (2017: 17) pula bahwa Islam dapat menjadi acuan nilai bagi upaya pencarian ilmu sosial profetik. Dengan demikian, tentu saja nilai itu diderivasi dari misi Islam yang bersifat universal yakni "humanisasi, liberasi, dan transendensi" sebagaimana tafsiran terhadap Surah Ali-Imron, (3: 110).

Berdasarkan uraian di atas, dapat dinyatakan bahwa sastra profetik memiliki tiga pilar utama. Tiga pilar itu adalah pilar humanisasi (amar ma'ruf), liberasi (nahi'munkar), dan transendensi (tu'minubillah). Sementara bembahasan terkait dengan tiga pilar profetik yang muncul dalam puisi-puisi Abdul Wachid B.S., yang sekaligus menjadi nilai-nilai yang dapat mendorong keberhasilan pendidikan karakter dalam perspektif profetik sebagaimana berikut ini.

a. Pilar Humanisasi atau Amar ma'ruf

Puisi profetik yang berperan dalam mendidik atau menyebarkan nilai-nilai humanisasi adalah puisi yang mengandung nilai-nilai kemanusiaan yang sekaligus dapat membentuk manusia sebagai pembaca menjadi pribadi yang berkarakter mulia. Karakter mulia, memang merupakan suatu hal yang universal. Oleh karena itu, perlu dirumuskan agar dapat diindentifikasi terkait dengan karakter tersebut. Roqib (2013: 145) menyampaikan bahwa pendidikan karakter dalam perspektif profetik yang pasti diwujudkan pada pilar humanisasi ialah mewujudkan individu yang memiliki nilai-nilai karakter seperti (1) menjaga persaudaraan, sekalipun dengan mereka yang berbeda agama, keyakinan, status sosial-ekonomi, dan tradisi, (2) memandang seseorang secara total meliputi aspek fisik dan psikisnya atau raga dan jiwanya, (3) menghindarkan berbagai bentuk kekerasan terhadap siapapun dan di mana pun termasuk kekerasan dalam rumah tangga (KDRT), dan (4) membuang jauh sifat kebencian. Setiap orang memiliki keterbatasan sehingga dimungkinkan melakukan kesalahan atau ketidaksempurnaan. Menerima kekurangan orang lain akan menghilangkan kebencian yang terkadang mendera jiwa seseorang.

Dengan demikian, beberapa hal yang menjadi karakter profetik terkait dengan humanisasi sebagaimana telah dijelaskan di atas dapat dilihat pada penjelasan atau analisis pada puisi-puisi Abdul Wachid B.S., salah satu puisinya yang terkait dengan humanisasi adalah puisi berikut ini:

\section{SINGAPURA \\ "sejak turun dari garuda di bandara changi \\ hatiku dihinggapi oleh rasa sepi tiba tiba tidak ada lagi ulas senyummu seperti orang lalulalang itu membeku"}

(Wachid B.S., 2017: 90)

Puisi di atas mencerminkan sebuah kehilangan rasa kemanusiaan di antara orang-orang yang sedang lalu lalang di Bandara Cangi Singapura. Artinya, lewat puisi tersebut sang penyair (aku liri) ingin menyadarkan terkait dengan rasa kemanusiaan yang telah hilang di antara sesama manusia itu. Suasana yang dihadapi oleh sang penyair (aku lirik) adalah rasa sepi dan tanpa sedikit senyuman dari orang-orang yang berada disekitarnya. Hal itulah, menjadi suatu masalah yang tidak boleh dibiarkan. Rasa kemanusaan yang telah hilang haruslah dihadirkan kembali. Senyum yang 
membeku di antara orang-orang lalu lang itu harus dihidupkan kembali sebegaimana tercermin pada larik //seperti orang lalulalang itu membeku//. Sang penyair (aku lirik) tidak ingin membiarkan suasana demikian terus berlangsung, tetepi yang diinginkan adalah menghidupkan kembali budaya senyum, berbagi senyum antara sesama, sekalipun dengan orang-orang yang tidak dikenali.

Dalam pandangan agama Islam, senyum adalah salah satu cara berbagi. Artinya, berbagi tidak selalunya dengan benda-benda yang bernilai mahal, seperti uang dan sebagainya. Namun, berbagi dapat juga dilakukan dengan sedikit senyuman yang tulus ikhlas dari hati yang terdalam. Senyum merupakan simbol dari rasa kasih sayang, setidaknya rasa kasih sayang atas dasar kemanusiaan sekalipun berbeda bangsa, suku, bahkan agama. Oleh karena itu, senyum merupakan hal penting yang sekaligus dapat mencerminkan sebuah perasaan atau solidaritas di antara manusia. Lewat puisi tersebut, Abdul Wachid B.S. berusaha menyadarkan para pembaca terkait dengan menjaga persaudaraan atas dasar kemanusiaan. Kemurahan hati yang kemudian dimunculkan lewat senyuman kepada sesama, menjadi suatu hal yang membangkit solidaritas antara sesama manusia.

Setelah itu, sang penyair (aku lirik) melanjutkan lagi bait puisinya agar pesan yang ingin disampaikan dapat berkesan pada hati pembaca. Pada bait berikut, sang penyair (aku lirik) ingin menyampaikan bahwa secara hakikat dalam kehudipan manusia tidak ada yang lebih berarti melebih ketulusan hati; hati yang baik, ikhlas dan sebagainya. Hal tersebut dapat diperhatikan pada bait berikut ini.

"sekalipun karpet merah terhampar di bandara ini hati kau aku tidak tergelar tanpa suara hanya jam dan pusat informasi

$$
\text { yang }
$$

bicara selebihnya perasaan gusar tidak banyak tanda larangan di negeri ini tetepi kau aku merasa di setiap tempat cctv semakin sempit ruang bercinta semakin terjepit waktu kita sebagai manusia"

(Wachid B.S., 2017: 90)

Dari kedua bait di atas, sang penyair (aku lirik) mencerminkan terkait dengan kemewahan atau kemajuan teklogi yang mungkin menjadi salah satu sebab yang membuat manusia menjadi semakin kehilangan rasa penting dalam hal beriteraksi dengan sesama manusia. Perhatikan larik ini //sekalipun karpet merah terhampar // di bandara ini hati kau aku tidak tergelar//, yang artinya kemewahan yang tidak diserti dengan keikhlasan hati manusia tidak akan berarti. Pada diksi "karpet merah" merupakan sebuah simbol yang menandakan kemewahan (pada konteks itu) yang digunakan oleh sang penyair (aku lirik). Namun, kemewahan baginya (sebagai manusia) tidaklah berarti melainkan kemewahan tersebut diikutsertakan juga dengan senyuman dan keikhlasan dari orang-orang yang lalu lalang, yang saling berbagi senyum, sapa, dan sebagainya layak sebagai seorang manusia yang memiliki rasa persaudaraan antara sesama. Hal itulah yang diinginkan oleh sang penyair (aku lirik). Bukan suasana sepi, diam, tanpa sedikitpun suara antara sesama yang saling bercerita atau sekadar berbasa basi. Larik berikut mencerminkan kesepian yang tidak disukai oleh sang penyair (aku lirik) // tanpa suara hanya jam dan pusat informasi yang // bicara selebihnya perasaan gusar//.

Dengan demikian, lewat puisi tersebut sang penyair (aku lirik) dapat mengekspresiakan rasa ketidaknyamanan dengan suasana tersebut. Artinya, hidup ini tidak dapat dibiarkan perasaan atau norma-norma kemanusiaan hilang dikarenakan munculnya berbagai 
teknologi yang dapat mewakili sifat-sifat interaksi atau komunikasi antara sesama manusia. Perhatikan larik-larik berikut // tidak banyak tanda larangan di negeri ini // tetepi kau aku merasa di setiap tempat cctv // semakin sempit ruang bercinta // semakin terjepit waktu kita sebagai manusia //. Larik-larik tersebut, sungguh mencerminkan keadaan sekarang. Kemajuan teklogi sebagai mana pada konteks ini, sang penyair (aku lirik) menggunakan diksi "cctv" sebagai wakil dari kemanujuan teknologi di hari ini. Memang, teknologi yang muncul sangatlah baik dan bagus dalam membantu keperluan-keperluan tertentu dalam kehidupan manusia. Namun, jika dengan munculnya berbagai teknologi membuat manusia terasa segan dalam menjalin rasa persaudaraan atau sekadar menjaga norma-norma kemanusiaan sebagaimana telah diwarisi oleh leluhur terdahulu, tentunya hal itu manjadi suatu masalah yang tidak boleh dibiarkan. Jika tidak, tentunya bangsa ini akan kehilangan sifat-sifat terpuji, seperti sopan santun, adab, budi pekerti, solidaritas sesama manusia dan sebagainya.

Tegas sang penyair (aku lirik) pada bait berikut terkait dengan senyum dan solidaritas yang sangat penting baginya dan bagi siapapun yang berbangsa manusia.

"bagiku senyuman adalah solidaritas tetepi bukan bunga kertas yang getas tetapi kamu bunga alami yang bersedekah wewangian saban hari"

(Wachid B.S., 2017: 90)

Dengai bait tersebut, semakin terlihat dan semakin jelas bahwa sang penyair (aku lirik) sangatlah mementingkan rasa solidaritas sesama manusia. Rasa solidaritas yang sempurna di hati manusia, tentunya akan dikembangkan lewat senyuman yang tulus ikhlas sebagai salah satu cara berbagi kebahagiaan antara sesama manusia. Berdasarkan penafsiran di atas, dapat disimpulkan bahwa lewat puisi tersebut sang penyair (aku lirik) menggambarkan nilai-nilai kemanusiaan yang telah hilang di antara sesama manusia sebagaimana terlihat di suatu bandara, yaitu di Bandara Cangi Singapura. Oleh karena itu, dengan wujudnya puisi ini dapat menjadi salah satu usaha sang penyair (aku lirik) dalam berupaya menghidupkan kembali rasa kemanusaiaan yang telah hilang itu. Jadi, hal-hal yang dikemukakan oleh sang penyait (aku lirik) pada puisi ini adalah sebagai nilai-nilai atau hal-hal yang mendidik para pembaca demi mewujudkan kembali rasa kemanusiaan. Di antaranya, yaitu (1) tanamkan kembali rasa persaudaraan anatara sesama manusia, sekalipun berbeda suku, bangsa, bahkan agama; (2) rasa solidaritas atas dasar kemanusiaan; dan (3) teknologi yang muncul janganlah menjadi suatu hal yang akan menghilangkan nilai-nilai luhur yang telah diwariskan oleh para pendahulu, sebagaimana sifat sopan santun, beradab, murah senyum dan sebagainya.

Dengan beberapa hal tersebut, tentunya menjadi hal yang sangat pengaruh bagi individu dalam menegakkan nilai-nilai karakter. Dengan demikianlah, puisi Abdul Wachi B.S. dapat dikatakan sebagai sebuah media atau sebuah edukasi dalam mendidik karakter anak bangsa agar menjadi pribadi yang berkarakter profetik. Di sinilah, terbukti bahwa puisi Abdul Wachid B.S. memiliki peran humanisasi atau peran mengajak manusia untuk kebaikan sebagaimana salah satu visi atau pilar profetik (kenabian).

\section{b. Pilar Liberasi atau Nahi'munkar}

Liberasi merupakan pilar yang berupaya membebaskan manusia dari berbagai penindasan. Pada konteks ini, akan membahas puisi Abdul Wachid B.S. yang mengandung nilai-nilai profetik yang 
terkait dengan pilar liberasi atau nahi' munkar. Nilai-nilai itulah akan menjadi sebuah usaha dalam memberi sumbangsih terhadap pendidikan karakter. Dalam arti, membangun karakter yang berani mencegah kemungkaran atau mencegah hal-hal yang tidak baik. Pendidikan karakter dalam perspektif profetik, Roqib (2013: 243) menjelaskan bahwa pada pilar liberasi akan terinternalisasi nilai-nilai karakter di antaranya: (1) memihak kepada kepentingan rakyat (wong cilik), tidak membebani rakyat dengan prosedur yang rumit atau biaya tinggi, (2) menegakkan keadilan, kebenaran, dan kesejahteraan, dengan membuat program dan sistem yang mampu menjaga diri dan lingkungan sosialnya untuk mendukung dan berpartisipasi, dan (3) memberantas kebodohan dan keterbelakangan sosialekonomi (kemiskinan) melalui pendidikan yang membebaskan dan pengembangan ekonomi kerakyatan.

Puisi Abdul Wachid B.S. yang mengandung nilai-nilai liberasi, yang artinya berusaha membebaskan manusia dari perbuatan-berbuatan aniaya atau sistem-sistem yang tidak adil dan sebagainya dapat dilihat pada puisi yang berjudul Bersandar Pada Pilar-pilar sebagaimana kutipan puisinya berikut ini.

Seseorang menguak keramaian

Dengan mengutip Anton Chekov

"Jika bangsa ini inginkan peradaban

Sejahterakan guru"

"Ya. Gaji kami bagai cacing kepanasan

Perut kosong, mata kunang-kunang

Hidup kami cukup tahu diri

Tak nuntut yang bukan-bukan"

(Wachid B.S. 2017: 5)

Pada kutipan puisi di atas, terlihat bahwa sang penyair (aku lirik) sangat mempeduli terhadap nasib para guru. Sang penyair (aku lirik) ikut menyuarakan keinginan para guru yang ingin memohon untuk ditambah gajinya. Puisi tersebut ditulis pada tahun sembilan puluhan, yang di mana saat itu gaji guru sangatlah sedikit bahkan tidak cukup untuk kebutuhan keluarga. Hal demikian, tentunya menjadi sebuah ketidakseimbangan atau tidak adil terhadap para guru. Pada hal sebuah bangsa tidak akan maju atau berkembang tanpa guru. Perhatikan larik ini // Jika bangsa ini inginkan peradaban // Sejahterakan guru, yang artinya lewat puisi ini sang penyair (aku lirik) memberi gambaran bahwa bangsa ini tidak akan maju jika para guru teraniaya, terdintas oleh sistem yang tidak adil atau sebagainya. Oleh sebeb itu, para guru haruslah diberi kehidupan yang layak. Dalam arti, berikan gaji kepada guru dengan layak sebagaimana profesi-profesi lain yang dapat mencukupi kebutuhan keluarga.

Sekalipun puisi itu ditulis pada tahun sembilan puluhan dan menggambarkan kondisi atau keadaan pada zaman itu, puisi itu masih relevan dengan keadaan sekarang. Sebagaimana diketahui bahwa gaji guru di Indonesia saat ini masih sangat diprihatin. Apa lagi para guru hinorer yang dapat gaji tidak seberapa bahkan tidak mencukupi kebutuhan hidup dalam keluarga. Dengan demikian, patutlah jika para guru berteriak memohon untuk gajinya dinaikkan dan sebagai seorang guru tentunya mereka tidak akan menuntut halhal yang tidak pantas dituntut sebagaimana disampaikan oleh sang penyair (aku lirik) // "Ya. Gaji kami bagai // cacing kepanasan // Perut kosong, mata kunang-kunang // Hidup kami cukup tahu diri // Tak nuntut yang bukan-bukan"//. Jadi, pada puisi di atas sang penyair (aku lirik) mengekspresikan simpatinya kepada para guru. Artinya, puisi itu ada unsur yang berupaya memberantaskan sistem yang tidak layak terhadap guru, protes 
terhadap ketidakadilah yang menimpa para guru dan sebagainya.

Sementara itu, hal demikian terdapat pula pada puisi yang berjudul Sumpah Buruh. Puisi Sumpah Buruh, sang panyair (aku lirik) menggukana kalimat "kita manusia indonesia" dengan cara repetisi. Adanya repetisi tersebut, tentunya memiliki efek makna tersendiri yang diinginkan oleh sang penyair (aku lirik) terhadap membaca. Perhatikan kutipan puisinya sebagai berikut.

\section{SUMPAH BURUH}

kita manusia indonesia

beralam satu alam indonesia

kita manusia indonesia

bermodal satu modal indonesia

kita manusia indonesia

bersumpah satu memanusiakan manusia

kita manusia indonesia

berani satu bayar buruh selayak keringatnya mai day, 1 mei 2016

Puisi di atas, tentunya berkaitan dengan para buruh. Hal itu, menjadi tanda bahwa sang penyair (aku lirik) mempeduli terhadap nasib para buruh yang kononnya gaji para buruh tidak seberapa atau tidak mencukupi kebutuhan dalam keluarga sebagaimana nasib para guru yang telah disampaikan lewat puisi sebelumnya. Jika begitu, buruh tersebut tidak jauh beda dengan apa yang disebut dengan budak atau diperbudakkan. Oleh karena itu, sebagai penyair profetik tidak boleh diam, artinya harus bersuara sebagai simpati terhadap para buruh tersebut.

Dengan demikian, muncullah puisi tersebut sebagai salah satu media dalam memperjuangkan nasib para buruh. Pada puisi di atas, sang penyair (aku lirik) menulis puisinya dengan menguatkan gaya repetisi kalimat "kita manusia indonesia" di setiap bait. Hal tersebut dilakukan oleh sang penyair (aku lirik), dimungkinkan untuk melahirkan kesan kepada pembaca bahwa "kita" para buruh adalah orang Indonesia yang seharusnya juga dapat bayaran atau gaji selayaknya sebagaimana pekerjaan-pekerjaan lain (sesama manusia Indonesia) yang ada di Indoneia. Dalam puisi Sumpah Buruk, sang penyair (aku lirik) memposisikan dirinya sebagai seorang buruh yang memperjuangkan nasibnya sendiri. Mungkin sang penyair (aku lirik) melihat bahwa selama ini para buruh dipandang rendah oleh masyarakat tertentu dan gajinya juga tidak sangat manusiawi. Oleh karena itulah, sang penyair (aku lirik) menyuarakan suara kecilnya sebagai simpati terhadap para buruh lewat puisinya.

Hal demikian, memang merupakan hal yang harus dicontohi oleh siapapun yang tidak suka terhadap sistem yang bersifat perbudakan atau tidak diperlakukan selayaknya manusia. Dalam arti, jika melihat saudara (sesama manusia) atau kaum tertentu diperlakukan dengan cara tidak manusiawi, maka sebagai seorang manusia tidak boleh diam begitu saja. Harus berani bersuara agar hal yang tidak baik itu dapat dihapuskan. Setidaknya ada simpati sekaligus lakukan apa saja yang mampu dilakukan sesuai dengan kemampuan masing-masing. Tentunya apa yang dilakukan itu, dapat membantu dan bermanfaat bagi saudara yang diperlakukan tidak manusiawi itu. Adanya simpati tersebut, merupakan salah satu tanda bahwa hati seseorang masih ada rasa tidak rela terhadap tingkah laku yang tidak manusiawi terhadap para buruh (sebagai manusia). Dengan demikian, dapat menunjukkan bahwa masih ada rasa kemanusiaan dan yang dilakukan itu tentunya memiliki unsur dalam memperjuangkan martabat seorang manusia atau memanusiakan manusia.

Berdasarkan paparan di atas, dapat disimpulkan bahwa puisi tersebut 
memiliki nilai atau memiliki unsur yang menegakkan pilar libersai yang meliputi: (1) menyuarakan rasa simpati dalam rangka berupaya membebaskan para buruh dari nasib yang kurang beruntung (sebagaimana mendapatkan gaji tidak selayaknya), (2) ada nilai-nilai yang ingin meningkatkan martabat kemanusiaan, dan (3) ada unsur ketidaksetujuan dengan apa yang sedang berlaku terhadap para buruh, artinya ada nilai yang ingin menghapuskan sistem yang tidak adil. Selain dari puisi di atas, masih banyak lagi puisi-puisi Abdul Wachid B.S. yang menyuarakan hal-hal terkait dengan perjuangan membebaskan manusia dari segala hal yang tidak bersifat manusiawi, dalam arti berusaha memanusiakan manusia sebagaimana visi profetik yang berada pada pilar liberasasi.

Sebagai peringatan terkait dengan liberasi, Kuntowijoyo (2001: 152) menegaskan bahwa pada pilar liberasi adalah berusaha untuk membebaskan manusia karena dalam peradaban modern pasar atau negara menyebabkan manusia mengabdi atau menjadi budak. Sebuah karya sastra yang menceritakan tentang orang yang berjuang untuk membebaskan kaum buruh, ia merupakan jenis pendidikan liberasi bagi pembacanya. Demikian juga hasil sastra yang menceritakan perjuangan kemanusiaan melawan negara yang menindas. Terkait dengan apa yang disampaikan oleh Kuntowijoyo itu, sangatlah tampak pada puisi-puisi karya Abdul Wachid B.S. Oleh karena itu, tidak diragukan lagi bahwa puisi-puisi Abdul Wachid B.S. mengandung nilai-nilai liberrasi sebagai salah satu pilar profetik yang dapat menjadi sumbangsih terhadap pendidikan karakter.

\section{c. Pilar Transendensi atau Iman}

Pada pilar transendensi ini, akan mengarahkan manusia pada ajaran yang mengandung nilai-nilai atau hal-hal yang berkaitan dengan hubungan seorang hamba (manusia) dengan Tuhannya, seperti mengenal Tuhan, beriman dan bertakwa kepada-Nya, dan sebagainya. Kuntowijowo (2001: 365) mengemukakan bahwa transendensi berasal dari kata bahasa Latin "transcendere" yang artinya "naik ke atas" dalam bahasa Inggris "to transcend" yang artinya menembus, melewati, melampaui, maksudnya perjalanan ke atas di luar. Sementara itu, Raqib (2011: 78) menjelaskan bahwa transendensi dapat diartikan hablum min Allah, ikatan spiritual yang mengikat antara manusia dengan Tuhan. Dengan demikian, hal-hal yang terkait dengan hubungan seorang hamba dengan TuhanNya amatlah banyak yang terdapat pada puisi-puisi Abdul Wachid B.S. Di antara puisinya sebagaimana berikut ini.

\section{Ungkapan Penari}

doa, sayang, telah kulayarkan

lewat dzikir yang

panjang dan nyeri

betapa senyap hutan lambang dalam malam

betapa gedebur lautnya menghempas

hingga hatiku

\section{meski malam telah larut seperti tinta yang mencat wajah \\ dan warna kota-kota berhala \\ tapi biarlah aku, sayang \\ menguji diri dalam namamu \\ yang berbunga dari kebun lidahku}

(Wachid B.S., 2003: 101)

Puisi di atas, memang tidak ada satu pun kata Tuhan atau Allah yang menjadi tanda bahwa puisi itu ada kaitannya antara hamba dengan Tuhan. Namun, secara makna yang tersirat dalam puisi itu adalah makna yang mengarah pada Tuhan sebagai Dzat yang dirindukan oleh sang penyair (aku lirik). Artinya, puisi tersebut adalah puisi yang berbicara terkait dengan hubungan seorang hamba dengan Sang Pencipta, yakni Allah SWT. Puisi di atas, sang penyair (aku lirik) memberi judul 
"Ungkapan Penari", yang artinya dapat diinterpretasikan sebagai sebuah "ungkapan, sebutan, dan sebagainya" yang dilantunkan oleh sang penyair (aku lirik). Diksi "penari" dapat diartikan sebaga diri sang penyair (aku lirik) sendiri yang melakukan tari. Tari pada konteks ini, bukanlah sebagaimana tari yang dikenal selama ini; tari yang menggunakan gerak tubuh dalam kegiatannya. Namun, maksud tari di sini adalah gerakan lidah yang dilakukan oleh sang penyair (aku lirik) dalam mengungkapkan doa dan dzikir sebagai tanda rindunya kepada Tuhan.

Doa dan dzikir yang dilantunkannya pada waktu malam dengan penuh sepi dan mengerikan oleh keadaan yang begitu gelap. Hal itu, dikemaskan sedemikian rupa oleh sang penyair (aku lirik) dengan diksi-diksi yang menarik sehingga puisi ini menjadi hidup dan dapat mengikat hati para pembaca. Perhatikan larik berikut // doa, sayang, telah kulayarkan // lewat dzikir yang // panjang dan nyeri // betapa senyap hutan lambang dalam malam // betapa gedebur lautnya menghempas // hingga hatiku//. Diksi "sayang" yang digunakan oleh sang penyair (aku lirik) dapat diartikan sebagai Tuhang Yang Maha Kasih Sayang. Kenapa demikian? Karena diksi-diksi sebelum dan sesudah diksi "sayang" ada diksi-diksi yang mendukung terkait dengan konteks ketuhanan, yaitu diksi "doa" dan "dzikir". Artinya, diksi tersebut umumnya mengarahkan kepada Tuhan. Jadi, lewat puisi tersebut sang penyair (aku lirik) ingin menyampaikan sebuah momen yang berlangsung terkait dengan hubungan seorang hamba dengan Tuhannya. Mungkin seorang hamba itu adalah sang penyair (aku lirik) sendiri atau bahkan orang lain (seperti para pembaca). Lantas, apa yang ingin disampaikan sang penyair (aku lirik) lewat puisinya kepada pembaca?

Melihat secara keseluruhan, puisi itu ingin menggambarkan terkait dengan seorang hamba (sebagai ciptaan-Nya) haruslah senantiasa berdoa dan berdzikir (ingat) kepada-Nya dalam keadaan apapun. Sebagaimana pada puisi di atas, sang penyair (aku lirik) menggambarkan bahwa dirinya yang senantiasa bahkan semakin asyik dengan berdzikir dan berdoa, sekalipun suasana semakin malam, gelap, ngeri dan sebagainya. Hal itu, sebagaimana dikemaskan pada larilarik ini // meski malam telah larut seperti tinta // yang mencat wajah // dan warna kota-kota berhala // tapi biarlah aku, sayang // menguji diri dalam namamu // yang berbunga dari kebun lidahku//. Perhatikan larik ini //menguji diri dalam namamu //, artinya sang penyair (aku lirik ) memohon kepada Tuhan untuk membiarkan dirinya untuk terus berdzikir (menyebut) nama-Mu (Tuhan) karena pada mulutnya tidak mau berhenti menyebut nama-nama Sang Maha Penyayang itu (Tuhan) // yang berbunga dari kebun lidahku//, sekalipun hari semakin laruk malam. Sang penyair (aku lirik) memohon dengan sangat untuk dzikir dan doa yang dilakukan itu tidak dihendikan oleh Tuhan (mungkin dihentikan dengan rasa mengantuk kemudian tidur). Permohonan sang penyair (aku lirik) dapat terlihat pada bait terakhir ini:

$$
\begin{gathered}
\text { jangan hentikan, jangan } \\
\text { aku penari } \\
\text { dalam gerak sunyimu } \\
\ldots . . \\
1988 \\
\text { (Wachid B.S., 2003: 101) }
\end{gathered}
$$

Larik //dalam gerak sunyimu//, artinya dalam keadaan sunyi itulah sang penyair (aku lirik) merasai lidahnya dapat bergerak menyebut nama-Mu. Oleh 
karena itu, biarkanlah dirinya sang penyair (aku lirik) terus menari dengan menggunakan gerak lidahnya demi berdoa dan berdzikir kepada-Nya, walaupun suasana atau keadaan waktu semakin malam dan menyepikannya.

Dari penafsiran di atas, dapat dimaknai bahwa sang penyair (aku lirik) menawarkan nilai-nilai transendensi kepada para pembaca. Nilai itulah, dapat dijadikan sebuah edukasi yang mendidik dalam membentuk karakter anak bangsa (pembaca) yang berprofetik. Artinya, dengan puisi tersebut (secara tidak langsung) sang penyair (aku lirik) ada upaya dalam mendidik atau membentuk karakter pembaca untuk tidak terputus hubungan dengan Yang Mahakuasa. Selain itu, juga dapat menguatkan unsur kepercayaan (iman) terhadap kekuatan suprantural; Dzat Yang Mahasegalanya. Jadi, dengan puisi tersebut sang penyair (aku lirik) menggambarkan bahwa ia sebagai manusia ciptaan Allah SWT., tidak boleh putus hubungan baiknya dengan Allah SWT. Harus senantiasa mengingat (rindu) kepada-Nya, baik dengan cara berdzikir menyebut nama-Nya maupun melakukan kebaikan atas dasar ingat perintah atau suruhan-Nya. Jika demikian, dapat dikatakan bahwa manusia adalah makhluk yang lemah, yang harus selalu bergantung kepada kekuatan Allah SWT. Oleh karena itu, sebagai manusia ciptaanNya harus menyadari hal itu agar tidak ada perasaan sombong atau sejenisnya.

Selain dari puisi di atas, masih banyak lagi puisi-puisi Abdul Wachid B.S. yang menguatkan unsur doa atau unsur kepercayaannya terhadap kekuatan supranatural; Dzat Yang Mahakuasa (Allah SWT). Di antaranya pada puisi singkat ini. Singkat, tetapi maknanya begitu dalam bahkah dapat mengeratkan dirinya sang penyair (aku lirik) dengan Dzat Yang Mahatinggi. Perhatikan puisi berikut ini:

\author{
Surat \\ tengah malam di jazirah \\ aku menerbangkan merpati putih \\ semoga sampai alamat kekasih \\ 1994 \\ (Wachid B.S., 2003: 26)
}

Puisi di atas adalah sebuah puisi yang dapat diinterpretasikan sebagai sebuah spiritual sang penyair (aku lirik) kepada Allah SWT. Judul puisi "surat", dapat diartikan sebagai sekumpulan ayat-ayat doa yang diterbangkan (yang dilontarkan) di waktu malam dengan penuh harapan sampai (diterima) kepada Allah. Kalimat //semoga sampai alamat kekasih//, diksi "kekasih" dapat diartikan sebagai Dzat Tuhan Yang Mahakasih sayang. Kemudian itu, bagaimana dengan larik sebelumnya yang menggunakan diksi "merpati putih"? Merpati adalah nama bagi binatang (burung) yang pada zaman dahulu menjadi alat untuk mengirimkan surat kepada alamat tertentu. Oleh sebeb itu, untuk mengirimkan surat (yang berupa kumpulan ayat-ayat doa) sang penyair (aku lirik) menggunakan diksi "merpati" sebagai media yang akan menerbangkan surat (kumpulan ayat-ayat doa) dengan penuh berharap sampai pada alamat kekasih, yakni Allah SWT. Hal itu, dapat dikatakan sebuah pengibaratan dalam perpuisian demi lahirnya unsur estetik atau keindahan-keindahan dalam puisi.

Dengan demikian, tidak diragukan lagi bahwa puisi adalah salah satu edukasi yang dapat mendidik anak bangsa (para pembaca) dalam membina karakter (profetik). Berdasarkan puisi Abdul Wachid B.S. di atas dapat disimpulkan bahwa lewat puisi itu sang penyair (aku lirik) menawarkan nilai-nilai ketuhanan (transendensi) kepada pembaca. Puisi, umumnya disampaikan dengan bahasa yang mengandung makna secara implisit. Jadi, ketika berhadapan dengan puisi, 
diperlukan sebuhan penghayatan atau sebuah renungan yang mendalam agar makna atau pesan yang sesungguhnya dapat dicapai oleh pembaca sebagaimana puisi di atas. Berdasarkan interpretasi terhadap puisi Abdul Wachid B.S. yang mengandung unsur transendensi di atas, dapat dirumuskan nilai-nilai atau pesan transendensi kepada pembaca, yaitu (1) kepercayaan (iman) seorang hamba terhadap kekuatan supranatural; Dzat Yang Mahasegalanya, (2) manusia (hamba yang lemah) haruslah senantiasa bergantung kepada Allah dengan banyak memohon atau berdoa kepada-Nya, dan (3) keberadaan manusia dalam keadaan apapun haruslah senentiasa mengingat kepada-Nya, baik dengan cara berdzikir maupun berbuat baik atas dasar ingat kepada perintah atau suruhan-Nya.

\section{KESIMPULAN}

Berdasarkan pembahasan terkait dengan pendidikan karakter dalam perspektif profetik yang ada pada puisipuisi Abdul Wachid B.S. dapat disimpulkan sebegai berikut: Pertama, puisi Abdul Wachid B.S. mempunyai nilainilai humanisasi yang dapat dijadikan sebuah edukasi yang mendidik para pembaca untuk mencapai pribadi yang berkarakter profetik sebagaimana pada pilar humanisasi terdapat beberapa hal berikut: (1) seruan untuk menjalin tali persaudaraan tanpa melihat suku, bangsa bahkan agama, (2) solidaritas atas dasar kemanusiaan, dan (3) nilai-nilai luhur yang diwarisi oleh para pendahulu haruslah dijaga dengan baik, jangan sampai hilang dikarenakan teknologi yang berkembang begitu pesat.

Kedua, pada pilar leberasi, puisi Abdul Wachid B.S. menyuarakan beberapa hal yang dapat membebaskan manusia atau meningkatkan martabat manusia, yaitu (1) rasa simpati dengan menyuarakan suara pembebasan bagi para buruh, (2) ada upaya dalam meningkatkan martabat manusia, dan (3) ada unsur tidak rela terhadap ketidakadilan yang berlaku di muka bumi ini. Ketiga, pilar transendensi sebagai pular utama dalam visi profetik. Pada pilar ini, puisi Abdul Wachid B.S. menyuarakan beberapa hal yang mendidik iman para pembaca demi dapat berhubungan baik dengan Tuhan, yaitu (1) menegakkan kepercayaan seorang hamba kepada Allah, (2) lemahnya manusia sehingga harus senantiasa bergantung kepada Allah, dan (3) harus senantiasa mengingatkan Allah dalam keadaan apapun.

Dengan demikian, dapat dikatakan bahwa uisi Abdul Wachid B.S. mengandung hal-hal yang dapat dijadikan sebuah usaha dan upaya dalam mendorong anak bangsa (para pembaca) untuk mencapai kesempurnaan pilar-pilar profetik tersebut. Seseorang yang dapat menyempurnakan tiga pilar profetik itu, tentunya akan terbentuklah pribadi yang memiliki karakter profetik (karakter kenabian).

\section{DAFTAR PUSTAKA}

Allport, G.W. (1964). Pattern and Growth in Personality. New York: Holt, Rinehart and Winston.

Eliade, Mircea. 1987. The Encyclopedia of Religion, Vol. 12. New York: Macmilan Publishing Company.

Hadi W.M., Abdul. 1989. Semangat Profetik Sastra Sufi dan Jejaknya dalam Sastra Modern. Dalam Majalah Ulumul Quran No. 1, Jakarta: Aksara Buana.

Hariyono, P. 2000. Pemahaman Kontekstual tentang Ilmu Budaya Dasar. Yogyakarta: Kanisius. 
Hilmy, M. 2008. Islam Profetik, Substansi

Nilai-nilai Agama dalam Ruang Publik. Yogyakarta: Kanisius.

Kuntowijoyo. 2001. Muslim Tanpa Masjid: Esai-esai Agama, Budaya, dan Politik dalam Bingkai Strukturalisme Transendental. Jakarta: Mizan.

. 2006. Maklumat Sastra Profetik. Yogyakarta: Grafindo Litera Media. . 2007. Islam sebagai Ilmu: Epistimologi, Metodologi, dan Etika. Yogyakarta: Tiara Wacana.

$\begin{array}{ccr}\text { 2017. } & \text { Paradigma } & \text { Islam: } \\ \text { Interpretasi } & \text { untuk } & \text { Aksi. } \\ \text { Yogyakarta: Tiara Wacana. } & \end{array}$

Kupperman, J.J. (1983). The Foundation of Morality. London: George Allen \& Unwin.

Kurniawan, Heru. 2009. Mistisisme Cahaya. Purwokerto: STAIN Press.

Pradopo, Rachmat Djoko. 2012. Pengkajian Puisi. Yogyakarta: Gajah Mada University Press.

Riffaterre, Michael. 1978. Semiotic of Poetry. Bloomington and London: Indiana Unversity Press.

Rocheah, M. (1973). The Nature of Human Volues. New York: The Free Press.

Roqib, Moh. 2011. Prophetic Education: Kontektualisasi Filsafat dan Budaya Profetik dalam Pendidikan. Purwokerto: STAIN Press Purwokerto.

Roqib. 2013. Pendidikan Karakter dalam Perspektif Profetik. Jurnal Pendidikan Karakter, Tahun III, Nomor 3, Oktober 2013.

Skolimowski, Henryk. 2004. Filsafat Lingkungan: Merangcang Taktik Baru untuk Menjalani Kehidupan. (Terjemahan Saut Pasaribu). Yogyakarta: Bentang Budaya.

Teew, A. 1984. Sastra dan Ilmu Sastra. Jakarta: Pustaka Jaya.
Wachid B.S., Abdul. 2003. Kumpulan Puisi Rumah Cahaya (Edisi Revisi). Yogyakarta: Gama Media. . 2003. Kumpulan Puisi Tunjammu Kekasih.Yogyakarta: Bentang Budaya. . 2017. Kumpulan Sajak Nun. Yogyakarta: Cinta Buku.

Wibowo, Agus. 2013. Pendidikan Karakter Berbasis Sastra. Yogyakarta: Pustaka Pelajar.

Wiyatmi. 2008. Pengantar Kajian Sastra. Yogyakarta: Pustaka. 